\title{
Endocrine cells and blood vessels work in tandem to generate hormone pulses
}

\author{
Marie Schaeffer ${ }^{1,2,3,4}$, David J Hodson ${ }^{1,2,3}$, Chrystel Lafont ${ }^{1,2,3}$ and Patrice Mollard ${ }^{1,2,3}$ \\ ${ }^{1}$ CNRS, UMR-5203, Institut de Génomique Fonctionnelle, F-34000 Montpellier, France \\ ${ }^{2}$ INSERM, U661, F-34000 Montpellier, France \\ ${ }^{3}$ Universités de Montpellier 1 and 2, UMR-5203, F-34000 Montpellier, France \\ ${ }^{4}$ Royal college of Surgeons in Ireland, $123 \mathrm{St}$ Stephens Green, Dublin 2, Ireland \\ (Correspondence should be addressed to P Mollard who is now at Department of Endocrinology, Institute of Functional Genomics, Montpellier 34094, France; \\ Email: patrice.mollard@igf.cnrs.fr)
}

\begin{abstract}
Hormones are dynamically collected by fenestrated capillaries to generate pulses, which are then decoded by target tissues to mount a biological response. To generate hormone pulses, endocrine systems have evolved mechanisms to tightly regulate blood perfusion and oxygenation, coordinate endocrine cell responses to secretory stimuli, and regulate hormone uptake from the perivascular space into the bloodstream. Based on recent findings, we review here the mechanisms that exist in endocrine systems to regulate blood flow, and facilitate coordinated cell activity and output under both normal physiological and pathological conditions in the pituitary gland and pancreas.
\end{abstract}

Journal of Molecular Endocrinology (2011) 47, R59-R66

\section{Introduction}

Finely tuned secretion of hormones is essential for regulating a multitude of basic body functions such as growth, metabolism, reproduction, and lactation. The pulsatile pattern of secretion of most hormones, resulting in burst like or episodic increases in circulating concentrations, is necessary for the generation of an appropriate downstream physiological response as well as the regulation of target cell function in both health and disease (Wildt et al. 1981, Matthews et al. 1983, Giustina \& Veldhuis 1998, Robinson \& Hindmarsh 1999). The generation of hormone pulses requires not only the energy demands of thousands of highly active endocrine cells to be met but also the temporally precise entry of hormone into the bloodstream. To achieve this, endocrine cell activity and output has to be temporally correlated with changes in blood flow, resulting in the replenishment of cell energy stores and the coordinated passage of hormone into the vasculature. Therefore, organisms have evolved mechanisms to tightly regulate blood perfusion and oxygenation, coordinate endocrine cell responses to secretory stimuli, and promote hormone uptake by blood vessels. This has prompted recent studies to explore whether endocrine systems possess different regulatory mechanisms to adjust blood flow velocity in response to metabolic demand, structurally organized populations of endocrine cells that favor coordinated responses, and specific mechanisms that permit hormone storage in the perivascular space before diffusion into the bloodstream (Bonnefont et al. 2005, Nyman et al. 2008, 2010, Hodson et al. 2010, Lafont et al. 2010, Sanchez-Cardenas et al. 2010). Since endocrine systems must display marked plasticity in response to varying physiological demand, these mechanisms must rapidly and reversibly adapt to the prevailing conditions (Robinson \& Hindmarsh 1999, Islam 2010). Moreover, defaults in hormone levels and their rhythms are signatures of many socioeconomically costly hormonal disorders (e.g. diabetes, hypopituitarism and infertility) (Knobil et al. 1994, Carroll et al. 1998, Islam 2010). Consequently, during the past 50 years, an impressive number of studies have been conducted to understand how hormone secretion is regulated and how hormone output can be modified/restored to reverse common hormonal disorders. Despite this, practically nothing is known about how hormones, locally secreted by endocrine cells, are captured by fenestrated capillaries and how blood vessel dynamics contribute to the formation of hormone pulses in the bloodstream. In light of recent findings (Nyman et al. 2008, 2010, Lafont et al. 2010), the aims of the current review are to describe the mechanisms which exist in the pituitary 
gland and the pancreas to: 1) regulate blood flow to adapt to varying metabolic demand during periods of plasticity in hormone release; 2) facilitate coordinated cell activity and output; and 3) regulate hormone entry into the bloodstream. In addition, we will detail the potential role that these mechanisms play in the development of pathologies related to endocrine dysfunction.

\section{Vascular system}

\section{Structure and common features}

Endocrine organs are typically irrigated by a network of fenestrated capillaries that allow transendothelial transit of medium-sized molecules (i.e. incoming secretagogs and released hormones) (Henderson \& Moss 1985). Pancreatic islets, for example, are embedded in a very dense microvascular network, that is, almost two- to three-fold denser than in surrounding exocrine tissue (Fig. 1). In addition, endocrine cells in islets are closely apposed to and polarized toward islet vascular endothelial cells (Bonner-Weir 1988), and produce factors that promote the formation of fenestrae (Lammert et al. 2003). In the pituitary gland, blood supply is provided by the hypothalamohypophyseal portal vasculature (Harris 1955, Daniel 1966, 1976), which ramifies into a specialized perfusion system to deliver hypothalamic signals to target pituitary cells (Harris 1947). Some pituitary cell types also form topologically organized networks in close apposition to the pituitary vasculature (Bonnefont et al. 2005, Lafont et al. 2010). What would be the benefit of such close relationships between vasculature and organized cell networks? As an example, proximity to highly fenestrated vessels may be of considerable advantage for
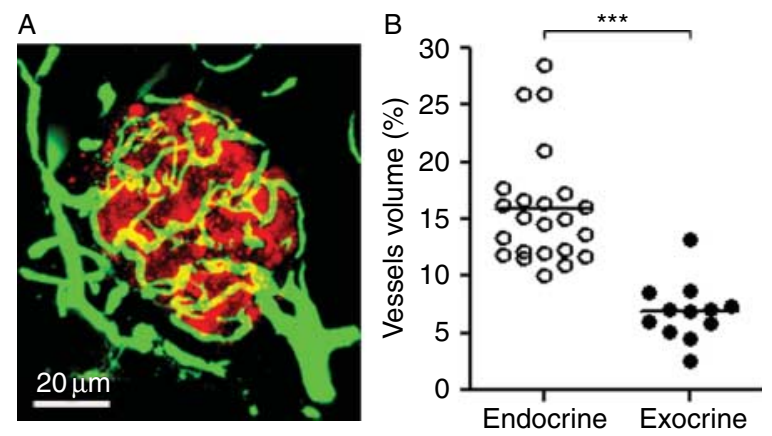

Figure 1 Vessels density in endocrine and exocrine pancreas. (A) Representative image of a mouse pancreatic islet. Green, blood vessels labeled with gelatin-FITC; red, insulin-producing cells. The image corresponds to a $30 \mu \mathrm{m}$ thick z-projection obtained using a Zeiss LSM 510 confocal microscope.

(B) Percentage volume occupied by vessels in endocrine and exocrine pancreas measured using Volocity software (Improvision, Coventry, UK). Statistical analysis was performed by a Student's $t$-test $\left.{ }^{\star \star \star} P<0.001\right)$. cells needing to respond synchronously to changes in metabolic demand. In fact, small gaseous molecules, such as oxygen, can freely diffuse from the blood to the tissue, following their gradient (Birol et al. 2007). However, to accommodate the increased metabolic demand observed in endocrine cells during secretory episodes, oxygen diffusion may not be rapid enough, and blood flow may require local adjustment to increase delivery. Although proper oxygen supply is essential for endocrine function, very little is known about how oxygen intake and consumption are temporally regulated during hormone release in the pituitary. Similarly, the mechanisms by which signaling molecules are distributed to endocrine cells remain elusive. The circulation of stimulatory or inhibitory molecules may be restricted by vessel pore size and require additional transport mechanisms. Indeed, fenestrations contain a diaphragm composed of radial fibrils converging on a central knob (Bearer \& Orci 1985, Stan et al. 1999), and may act to regulate molecule diffusion from the blood to the perivascular space, influencing the rate of transcapillary transport of hormones toward the bloodstream. The microvasculature in endocrine organs may therefore, in addition to dispersing incoming signaling molecules and clearing secreted products, function as a gatekeeper that shapes the distribution and the clearance of hormones from the gland.

\section{Regulation of blood flow}

It is generally believed that an increase in endocrine cell activity during hormone secretion leads to increased blood flow to meet metabolic demand. Although the exact mechanisms remain unclear, release of vasoactive substances most likely plays an important role. During an acute deficit in oxygen supply, the coordinated release of highly diffusible vasoactive factors, such as nitric oxide (NO), is triggered (Prabhakar 2006, Kemp et al. 2009), inducing changes in mural cell tone. Mural cells, usually vascular smooth muscle cells (VSMC), line vessel walls and regulate blood flow. However, VSMC are absent from the pituitary, and are only found on large efferent arterioles in murine pancreatic islets (Lai et al. 2007). Nevertheless, the microvasculature in these tissues possesses specific regulatory mechanisms to allow the control of blood flow (Satoh et al. 1989). Pericytes, another type of mural cell related to VSMC, are putative candidates since they can induce vessel constriction and modify vascular diameter and blood flow (Rucker et al. 2000, Peppiatt et al. 2006). These cells have been detected in both the pituitary and pancreatic islets (Farquhar 1961, Nakamura et al. 1995, Richards et al. 2010) and may play an important role in blood flow regulation (Gaengel et al. 2009). NO, the main regulator of vascular tone, can be produced by a variety 
of cell types. In the pituitary, different endocrine cells express neuronal NO synthase (nNOS; Hokfelt et al. 1994, Andric et al. 2001, Tsumori et al. 2002), and vascular endothelial cells express endothelial NO synthase (eNOS; Garcia-Cardena et al. 1996). Both nNOS and eNOS produce NO using L-arginine as substrate. Various peptides, including hypothalamic neuropeptides and pituitary hormones, can modulate NOS activity and vascular tone (Boger 1999, Tsumori et al. 2002). NO, in turn, can modulate secretory activity and hormone output (Gonzalez-Hernandez \& Gonzalez 2000). In pancreatic islets, both endothelial cells and $\beta$-cells express NOS (Corbett et al. 1992a,b, Alm et al. 1999) and NO influences both regulation of islet perfusion and hormone secretion (Salehi et al. 1996). In rodents, glucose considerably increases blood flow specifically at the level of islets (Jansson \& Hellerstrom 1983, Nyman et al. 2010) through the induction of vasodilation by the central nervous system as well as local NO synthesis (Jansson \& Hellerstrom 1986, Carlsson et al. 1999). On the contrary, blood flow rate remains unchanged in the exocrine pancreas. This differential regulation of blood flow may implicate sphincter-like activity of endothelial cells and extra-islet gates (McCuskey \& Chapman 1969, Moldovan \& Brunicardi 2001). Shunting may be partly achieved by pericytes, which are present in the pancreas (Richards et al. 2010), although this remains to be investigated. In addition, insulin decreases islet blood flow (Jansson et al. 2007) through induction of normoglycemia as well as direct affects on vascular tone (Sparrow \& Beckingham 1989, Montagnani et al. 2001). Figure 2 summarizes potential mechanisms for blood flow regulation in the islets.

\section{Blood flow measurement and oxygen consumption}

Direct in vivo measurement of blood flow in endocrine organs has been particularly challenging due to lack of appropriate models which allow identification of cells in situ and technical constraints on imaging deep structures. Only recently have high temporal and spatial resolutions been combined to measure islet blood flow velocities under differing states of glycemia (Nyman et al. 2010). In the pituitary, direct measurements of differences in blood flow rates in individual vessels or the relationship between local blood flow and secretion of hormone has remained unresolved. By taking advantage of transgenic mice expressing eGFP-tagged GH cells (Magoulas et al. 2000) and a novel imaging approach using long working distance objectives, we have been able to measure blood supply dynamics and oxygen consumption in relation to GH pulse generation in a physiologically relevant context (Lafont et al. 2010; Fig. 3). We were particularly interested in how blood flow and tissue oxygen partial pressures $\left(\mathrm{Ptiss}, \mathrm{O}_{2}\right)$ varied

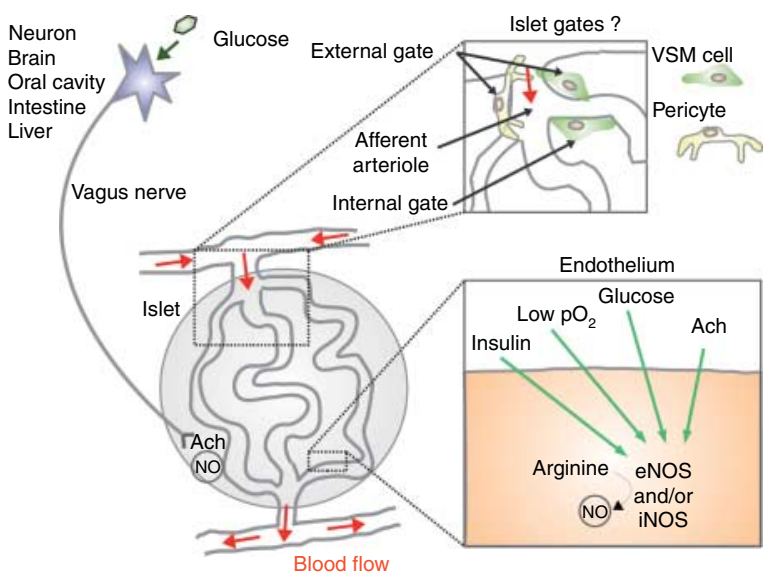

Figure 2 Potential mechanisms for blood flow regulation in the pancreatic islets. Stimulation of glucose-sensitive neurons increases islet blood flow through indirect actions on parasympathetic outflow (vagus) and direct actions on islet vasoactive substance release (acetylcholine and NO). Glucose, acetylcholine, low $\mathrm{pO}_{2}$ and insulin can stimulate NOS expression in endothelial cells, eliciting relaxation of pericytes and vascular smooth muscle cells (presumably located on the internal and/or external islet gates) and leading to increased blood flow. Ach, acetylcholine; Enos, endothelial nitric oxide synthase; iNOS, inducible nitric oxide synthase; NO, nitric oxide; VSM, vascular smooth muscle. Red arrows indicate blood flow direction.

during hormone release following stimulation with GHRH, the major GH secretagog. Using plasma fluorescently labeled with large molecular weight dextrans, we were able to measure red blood cell (RBC) velocity (appearing as shadows) and found that blood flow was independent of vessel diameter and variable within the pituitary. Oxygen partial pressures $\left(\mathrm{Ptiss}, \mathrm{O}_{2}\right.$ ) were measured using Clark-type $\mathrm{O}_{2}$ microsensors (Bergsten et al. 2002), and revealed little variation in resting conditions. On the contrary, following GHRH challenge, RBC velocity, GH cell electrical activity, and Ptiss, $\mathrm{O}_{2}$ deflections increased, coincident with the appearance of a GH pulse in the bloodstream (Fig. 3). To confirm that GH cell coordinated activity was positively correlated with increased oxygen consumption, acute pituitary slices, in which oxygen supply is stable, were used (Lafont $e t$ al. 2010). Therefore, we demonstrated for the first time in vivo that GHRH-induced GH secretion was associated with coordinated GH cell activity, increases in local blood flow and changes in partial oxygen pressure within GH cell clusters (Lafont et al. 2010; Fig. 3). It should be noted, however, that the ability of GHRH to activate nNOS and increase NO production, as opposed to a compensatory increase in blood flow in direct response to tissue hypoxia, may account for the observed increases in blood flow (Boger 1999, Tsumori et al. 2002). Potential regulatory mechanisms that may exist in the pituitary to modify blood flow following GHRH stimulation have been proposed (Schaeffer et al. 2010). 
These include upregulation of inducible NO synthase (iNOS), eNOS and cyclooxygenase activity in pituitary cells, resulting in release of NO and prostaglandins. These potent vasodilators may then induce relaxation of pericytes, leading to the increased blood flow which is observed in response to the GHRH-induced decrease in Ptiss, $\mathrm{O}_{2}$. In islets, comparable episodes of oxygen consumption were observed simultaneously with increases in $\beta$-cell calcium-spiking activity (Jung et al. 2000). However, NOS inhibition in islets does not affect oxygen tension following glucose challenge suggesting that increases in islet blood flow cannot be simply explained by metabolic demand for oxygen (Carlsson et al. 2002a). As insulin has known vasodilator properties (Sparrow \& Beckingham 1989, Montagnani et al. 2001), local blood flow increase may be a consequence of hormone secretion as opposed to an increase in oxygen consumption. Other mechanisms, such as adenosine production associated with islet metabolism, may favor local increases in blood flow velocity (Carlsson et al. 2002b).
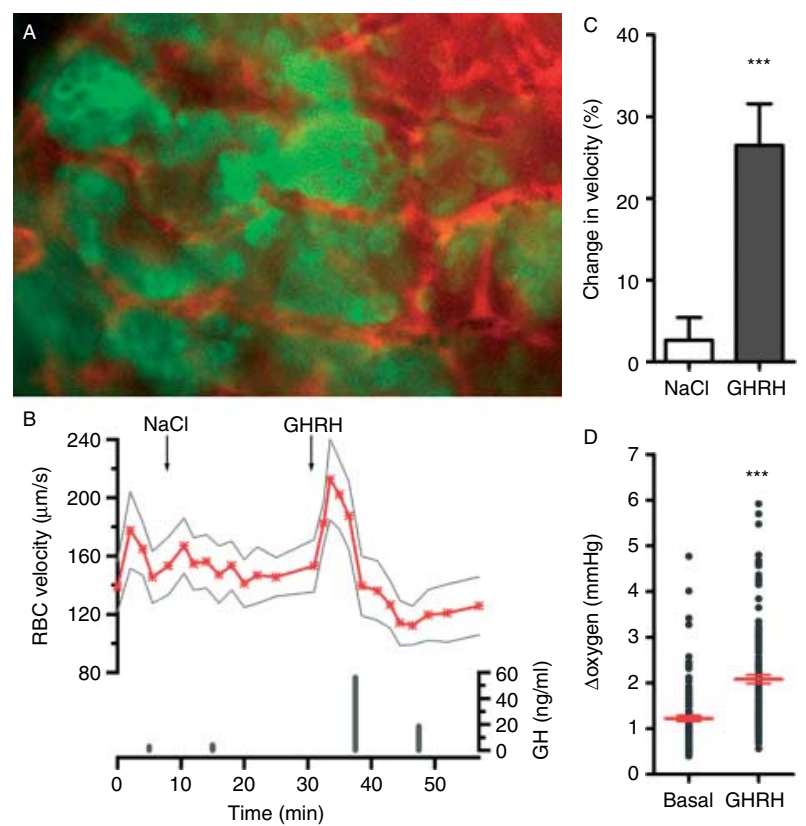

Figure $3 \mathrm{GHRH}$ stimulation induces a local increase in red blood cell velocity, and a modification of oxygen consumption by $\mathrm{GH}$ cells. (A) GH cell clusters in the pituitary of a living GH-eGFP transgenic mouse. Green, GH-eGFP cells; red, blood vessels labeled with Rhodamine B-conjugated dextran injected intravenously. (B) Red blood cell (RBC) velocity and GH serum levels increase after i.v. injection of GHRH $(1 \mu \mathrm{g})$. Mean velocity (red line) and S.E.M. (gray lines) from six individual vessels is represented. (C) Variation in RBC velocity 5 min after i.v. injections of either $\mathrm{NaCl}$ or $\mathrm{GHRH}(1 \mu \mathrm{g})$. (D) $\mathrm{O}_{2}$ deflection amplitude 5 min after i.v. injections of either $\mathrm{NaCl}$ or $\mathrm{GHRH}(1 \mu \mathrm{g})$. Statistical analysis was performed using Student's $t$-test $\left({ }^{\star \star \star} P<0.001\right)$.

\section{Endocrine cell coordination}

Release of hormones from endocrine cells is evoked by humoral, neural, or hormonal stimuli. Most secretory stimuli are carried by the blood and must diffuse rapidly into the endocrine parenchyma to reach their targets. We modeled the entry of such stimuli by monitoring the distribution of $4 \mathrm{kDa}$ dextrans (approximate size of most hypothalamic secretagogs) from the bloodstream into the parenchyma (Lafont et al. 2010). Following i.v. injection, the $4 \mathrm{kDa}$ marker spread rapidly and radially from the vessels and the extent of diffusion of the $4 \mathrm{kDa}$ fluorescent marker was limited in distance to $<100 \mu \mathrm{m}$ from the injection site due to rapid capture by vessels. These results suggest that groups of pituitary cells are exposed to differential secretagog concentration gradients and that other mechanisms must exist to allow coordinated cell responses in the face of such heterogeneous stimulation.

For many years, it was assumed that endocrine cell types in the pituitary gland were randomly distributed throughout the parenchyma and that changes in the secretion of hormone-releasing factors from hypothalamic nerve terminals were primarily responsible for the observed plasticity in pituitary hormone secretion. However, this does not fit with studies in dispersed pituitary cells, where the ability of hypothalamic releasing hormones to evoke endocrine secretion is 100 - to 1000 -fold lower than that observed in the intact tissue (Tannenbaum et al. 1976, Sartor et al. 1985). We have previously shown that GH-producing cells in the pituitary gland are arranged into a topologically organized network in close association with the pituitary vasculature. By virtue of this three-dimensional organization, $\mathrm{GH}$ cells are able to mount large-scale coordinated responses following arrival of secretagog, increasing the amplitude and efficiency of cell signaling events and hormone secretion (Bonnefont et al. 2005, Sanchez-Cardenas et al. 2010). These responses are severely impaired when the GH cell network is 'broken' using transgenic approaches (Waite et al. 2010), implicating structural integrity in the coordinated transmission of cell-cell information. Therefore, endocrine cell networks may represent a physical mechanism that facilitates coordinated activity following encounter with heterogeneous stimuli. Like their counterparts in the pituitary, endocrine cells in the islets of Langerhans are topologically organized in a non-random manner. Murine islets consist of a $\beta$-cell core, principally responsible for the maintenance of blood glucose concentrations through the secretion of insulin, surrounded by a mantle of $\alpha-, \delta$-, and PP-cells (Bonner-Weir et al. 1993). Of particular note, $\beta$-cells are homotypically linked by gap junctions, allowing emergence of coordinated calcium oscillations which 
drive calcium-dependent secretory bursts of insulin in response to glucose stimulus (Santos et al. 1991, Ravier et al. 1999, 2005, Kjems et al. 2002, Benninger et al. 2008). Furthermore, intimate molecular crosstalk between $\beta$-cells and endothelial cells is essential for endocrine pancreas function (Kragl \& Lammert 2010).

\section{Regulation of hormone uptake}

Endocrine cells respond to stimuli by generating coordinated changes in signaling molecules (i.e. cytosolic calcium) that are responsible for driving secretion of hormones into the extracellular space (Schlegel et al. 1987, Mollard \& Schlegel 1996, Stojilkovic et al. 2005). Hormones are dynamically collected by fenestrated capillaries to make pulses, which are then decoded by target tissues to mount a biological response. The exocytosis of hormones packed into docked granules is a very fast event (ms-s range) and quickly stops after cessation of stimulus (Tse et al. 1993, Mollard et al. 1995). However, while the pituitary GH cell network discharges signaling and exocytotic events rapidly in response to GHRH, the appearance of GH pulses in the bloodstream requires several to dozens of minutes (Clark et al. 1987). Such enigma is widely observed in most, if not all endocrine glands. As another example, human islets display a wide variety of electrical and calcium-spiking activities ex vivo, but their roles in mediating pulsatile secretion of insulin (pulses at $\sim 5$ min intervals) remain unanswered since the fate of secreted insulin between the $\beta$-cells and the lumen of fenestrated capillaries is not known (Islam 2010). Although a perivascular space was identified in the 1950s (Rinehart \& Farquhar 1955), its role remains widely unexplored, and it has been proposed to act as a modulator of hormone uptake by fenestrated capillaries. For instance, GH released upon GHRH stimulation may be stored in the perivascular space long enough to play a role in the control of blood vessel density and maintenance (Sonntag et al. 2000).

To model hormone uptake by capillaries and investigate the role of the perivascular space in hormone storage in the pituitary gland, we locally injected fluorescent markers of different sizes $(4 \mathrm{kDa}$ for ACTH; $20 \mathrm{kDa}$ for GH, PRL) into the endocrine parenchyma of anesthetized animals (Lafont et al. 2010). We found that, although passage toward blood vessels was rapid, significant amounts of larger markers remained sequestered in what appeared to be a perivascular compartment (Fig. 4). These results suggest that $\mathrm{GH}$ pulse generation is not simply a $\mathrm{GH}$ cell network response, but is shaped by the tissue microenvironment, involving a role of the perivascular space as a gatekeeper or rate-limiting step for hormone uptake by fenestrated pituitary capillaries. Although fluorescent sugars present the advantage of possessing
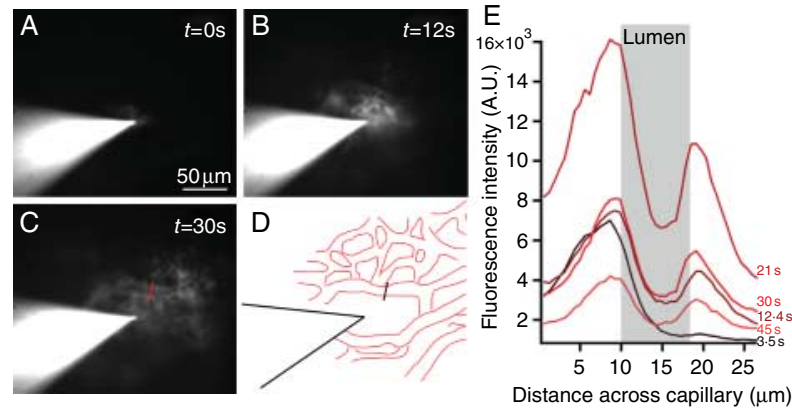

Figure 4 Clearance of products injected into the extracellular space at the vascular level. $(A-C)$ Single pulse injection by iontophoresis of a $20 \mathrm{kDa}$ fluorescent dextran into the pituitary parenchyma of a living mouse. Time post-injection is indicated. Accumulation of the molecule around the blood vessels is visible at $t=30 \mathrm{~s}$ post-injection (C). (D) Schematic representation of the vessels (red) around the injection zone. (E) Clearance of the $20 \mathrm{kDa}$ molecule measured by variation in fluorescence intensity across a vessel (red line in $C$ and black line in D). Fluorescence increases up to $21 \mathrm{~s}$ post-injection and declines thereafter, although it still remains detectable $45 \mathrm{~s}$ post-injection, suggesting the molecule is stored in the perivascular space.

a large number of fluorescent markers per molecule, development in the future of cost-effective fluorescently labeled bioactive hormones, with emission properties detectable using in vivo imaging, will provide invaluable tools to study diffusion and transport of hormones in their native environment. Furthermore, such methods will help resolve whether the mechanisms of hormone transport across the endothelial barrier involve passive diffusion through fenestrae and/or saturable receptormediated processes, a matter still debated for most transcapillary hormone transports (King \& Johnson 1985, Steil et al. 1996, Hamilton-Wessler et al. 2002).

\section{Importance in pathology}

There is increasing evidence that vasculopathies may precede a range of endocrine diseases such as diabetes mellitus and pituitary tumors. Extended literature in the past decade has provided evidence for dynamic interactions between blood vessels and pancreatic $\beta$-cells, which are pivotal for enhancing insulin expression and $\beta$-cell proliferation in response to increased insulin demand during body growth, pregnancy, and virtually all conditions associated with insulin resistance. A failure in this adaptive response might contribute to the onset of diabetes (Eberhard et al. 2010). In addition, abnormalities in islet blood flow regulation have been described in animal models of functional stress on $\beta$-cells (Atef $e$ al. 1992, Jansson 1994, Svensson et al. 1994, 2000, Carlsson et al. 1998), as well as following rejection of experimentally transplanted islet grafts (Olsson et al. 2000). Lastly, impairment of pericyte recruitment, which may interfere with blood flow regulation, has also been implicated in 
diabetes (Clee et al. 2006). In the pituitary gland, deregulation of pituitary blood flow has been observed in adenomas (Turner et al. 2003) and acquired hypopituitarism (Dusick et al. 2008). The former are a significant cause of morbidity in both rodents and humans, and increases in angiogenic factor expression, NOS immunoreactivity and blood flow have been detected in adenomatous tissue (Kemeny et al. 1987, Heaney et al. 2002, Kruse et al. 2002). Altogether, the exact pathophysiological mechanisms involved in these modifications remain unclear. Hence, the study of the microcirculation may help unveil the contribution of flow abnormalities to the development of endocrine pathology.

\section{Declaration of interest}

The authors declare that there is no conflict of interest that could be perceived as prejudicing the impartiality of the research reported.

\section{Funding}

All authors were supported by grants from the Agence Nationale de la Recherche (ANR) (Pit-Net), Institut National de la Santé et de la Recherche Médicale (INSERM), Centre National de la Recherche Scientifique (CNRS), the Universities of Montpellier 1 and 2, National Biophotonics and Imaging Platform (Ireland) (NBIPI), Fondation pour la Recherche Medicale (FRM), Réseau National des Génopoles, Institut Fédératif de Recherches No. 3 and Région Languedoc Roussillon.

\section{References}

Alm P, Ekstrom P, Henningsson R \& Lundquist I 1999 Morphological evidence for the existence of nitric oxide and carbon monoxide pathways in the rat islets of Langerhans: an immunocytochemical and confocal microscopical study. Diabetologia 42 978-986. (doi:10.1007/s001250051256)

Andric SA, Kostic TS, Tomic M, Koshimizu T \& Stojilkovic SS 2001 Dependence of soluble guanylyl cyclase activity on calcium signaling in pituitary cells. Journal of Biological Chemistry $\mathbf{2 7 6}$ 844-849. (doi:10.1074/jbc.M004406200)

Atef N, Ktorza A, Picon L \& Penicaud L 1992 Increased islet blood flow in obese rats: role of the autonomic nervous system. American Journal of Physiology 262 E736-E740.

Bearer EL \& Orci L 1985 Endothelial fenestral diaphragms: a quickfreeze, deep-etch study. Journal of Cell Biology 100 418-428. (doi:10.1083/jcb.100.2.418)

Benninger RK, Zhang M, Head WS, Satin LS \& Piston DW 2008 Gap junction coupling and calcium waves in the pancreatic islet. Biophysical Journal 95 5048-5061. (doi:10.1529/biophysj.108. 140863)

Bergsten P, Westerlund J, Liss P \& Carlsson PO 2002 Primary in vivo oscillations of metabolism in the pancreas. Diabetes 51 699-703. (doi:10.2337/diabetes.51.3.699)

Birol G, Wang S, Budzynski E, Wangsa-Wirawan ND \& Linsenmeier RA 2007 Oxygen distribution and consumption in the macaque retina. American Journal of Physiology. Heart and Circulatory Physiology 293 H1696-H1704. (doi:10.1152/ajpheart.00221.2007)

Boger RH 1999 Nitric oxide and the mediation of the hemodynamic effects of growth hormone in humans. Journal of Endocrinological Investigation 22 75-81.
Bonnefont X, Lacampagne A, Sanchez-Hormigo A, Fino E, Creff A, Mathieu MN, Smallwood S, Carmignac D, Fontanaud P, Travo P et al. 2005 Revealing the large-scale network organization of growth hormone-secreting cells. PNAS 102 16880-16885. (doi:10.1073/ pnas.0508202102)

Bonner-Weir S 1988 Morphological evidence for pancreatic polarity of beta-cell within islets of Langerhans. Diabetes 37 616-621. (doi:10. 2337/diabetes.37.5.616)

Bonner-Weir S, Baxter LA, Schuppin GT \& Smith FE 1993 A second pathway for regeneration of adult exocrine and endocrine pancreas. A possible recapitulation of embryonic development. Diabetes 42 1715-1720. (doi:10.2337/diabetes.42.12.1715)

Carlsson PO, Sandler S \& Jansson L 1998 Pancreatic islet blood perfusion in the nonobese diabetic mouse: diabetes-prone female mice exhibit a higher blood flow compared with male mice in the prediabetic phase. Endocrinology 139 3534-3541. (doi:10.1210/en. 139.8.3534)

Carlsson PO, Iwase M \& Jansson L 1999 Stimulation of intestinal glucoreceptors in rats increases pancreatic islet blood flow through vagal mechanisms. American Journal of Physiology 276 R233-R236.

Carlsson PO, Jansson L \& Palm F 2002a Unaltered oxygen tension in rat pancreatic islets despite dissociation of insulin release and islet blood flow. Acta Physiologica Scandinavica 176 275-281. (doi:10.1046/j.1365-201X.2002.01049.x)

Carlsson PO, Olsson R, Kallskog O, Bodin B, Andersson A \& Jansson L $2002 b$ Glucose-induced islet blood flow increase in rats: interaction between nervous and metabolic mediators. American Journal of Physiology. Endocrinology and Metabolism 283 E457-E464. (doi:10.1152/ajpendo.00044.2002)

Carroll PV, Christ ER, Bengtsson BA, Carlsson L, Christiansen JS, Clemmons D, Hintz R, Ho K, Laron Z, Sizonenko P et al. 1998 Growth hormone deficiency in adulthood and the effects of growth hormone replacement: a review. Growth Hormone Research Society Scientific Committee. Journal of Clinical Endocrinology and Metabolism 83 382-395. (doi:10.1210/jc.83.2.382)

Clark RG, Carlsson LM \& Robinson IC 1987 Growth hormone secretory profiles in conscious female rats. Journal of Endocrinology 114 399-407. (doi:10.1677/joe.0.1140399)

Clee SM, Yandell BS, Schueler KM, Rabaglia ME, Richards OC, Raines SM, Kabara EA, Klass DM, Mui ET, Stapleton DS et al. 2006 Positional cloning of Sorcs1, a type 2 diabetes quantitative trait locus. Nature Genetics 38 688-693. (doi:10.1038/ng1796)

Corbett JA, Wang JL, Hughes JH, Wolf BA, Sweetland MA, Lancaster JR Jr \& McDaniel ML 1992 $a$ Nitric oxide and cyclic GMP formation induced by interleukin 1 beta in islets of Langerhans. Evidence for an effector role of nitric oxide in islet dysfunction. Biochemical Journal 287 229-235.

Corbett JA, Wang JL, Sweetland MA, Lancaster JR Jr \& McDaniel ML $1992 b$ Interleukin 1 beta induces the formation of nitric oxide by beta-cells purified from rodent islets of Langerhans. Evidence for the beta-cell as a source and site of action of nitric oxide. Journal of Clinical Investigation 90 2384-2391. (doi:10.1172/ JCI116129)

Daniel PM 1966 Blood supply of hypothalamus and pituitary gland. British Medical Bulletin 22 202-208.

Daniel PM 1976 Anatomy of the hypothalamus and pituitary gland. Journal of Clinical Pathology 7 1-7. (doi:10.1136/jcp.s1-7.1.1)

Dusick JR, Wang C, Cohan P, Swerdloff R \& Kelly DF 2008 Chapter 1: pathophysiology of hypopituitarism in the setting of brain injury. Pituitary 11 123-126. (doi:10.1007/s11102-008-0130-6)

Eberhard D, Kragl M \& Lammert E 2010 'Giving and taking': endothelial and beta-cells in the islets of Langerhans. Trends in Endocrinology and Metabolism 21 457-463. (doi:10.1016/j.tem.2010. 03.003)

Farquhar MG 1961 Fine structure and function in capillaries of the anterior pituitary gland. Angiology 12 270-292. (doi:10.1177/ 000331976101200704) 
Gaengel K, Genove G, Armulik A \& Betsholtz C 2009 Endothelialmural cell signaling in vascular development and angiogenesis. Arteriosclerosis, Thrombosis, and Vascular Biology 29 630-638. (doi:10.1161/ATVBAHA.107.161521)

Garcia-Cardena G, Oh P, Liu J, Schnitzer JE \& Sessa WC 1996 Targeting of nitric oxide synthase to endothelial cell caveolae via palmitoylation: implications for nitric oxide signaling. PNAS 93 6448-6453. (doi:10.1073/pnas.93.13.6448)

Giustina A \& Veldhuis JD 1998 Pathophysiology of the neuroregulation of growth hormone secretion in experimental animals and the human. Endocrine Reviews 19 717-797. (doi:10.1210/er.19.6.717)

Gonzalez-Hernandez T \& Gonzalez MC 2000 Gender differences and the effect of different endocrine situations on the NOS expression pattern in the anterior pituitary gland. Journal of Histochemistry and Cytochemistry 48 1639-1648. (doi:10.1177/002215540004801207)

Hamilton-Wessler M, Ader M, Dea MK, Moore D, Loftager M, Markussen J \& Bergman RN 2002 Mode of transcapillary transport of insulin and insulin analog NN304 in dog hindlimb: evidence for passive diffusion. Diabetes 51 574-582. (doi:10.2337/diabetes. 51.3.574)

Harris GW 1947 The blood vessels of the rabbit's pituitary gland, and the significance of the pars and zona tuberalis. Journal of Anatomy 81 343-351. (doi:10.1002/aja.1000810303)

Harris GW 1955 The function of the pituitary stalk. Bulletin of the Johns Hopkins Hospital 97 358-375.

Heaney AP, Fernando M \& Melmed S 2002 Functional role of estrogen in pituitary tumor pathogenesis. Journal of Clinical Investigation 109 277-283. (doi:10.1172/JCI0214264)

Henderson JR \& Moss MC 1985 A morphometric study of the endocrine and exocrine capillaries of the pancreas. Quarterly Journal of Experimental Physiology 70 347-356.

Hodson DJ, Molino F, Fontanaud P, Bonnefont X \& Mollard P 2010 Investigating and modelling pituitary endocrine network function. Journal of Neuroendocrinology 22 1217-1225. (doi:10.1111/j.13652826.2010.02052.x)

Hokfelt T, Ceccatelli S, Gustafsson L, Hulting AL, Verge V, Villar M, Xu XJ, Xu ZQ, Wiesenfeld-Hallin Z \& Zhang X 1994 Plasticity of NO synthase expression in the nervous and endocrine systems. Neuropharmacology 33 1221-1227. (doi:10.1016/0028-3908(94)90020-5)

Islam MS (Ed) 2010 The Islets of Langerhans. Volume 654 of Advances in Experimental Medicine and Biology. Dordrecht: Springer. (doi:10.1007/978-90-481-3271-3)

Jansson L 1994 The regulation of pancreatic islet blood flow. Diabetes/Metabolism Reviews 10 407-416. (doi:10.1002/dmr.5610100405)

Jansson L \& Hellerstrom C 1983 Stimulation by glucose of the blood flow to the pancreatic islets of the rat. Diabetologia $2545-50$. (doi:10.1007/BF00251896)

Jansson L \& Hellerstrom C 1986 Glucose-induced changes in pancreatic islet blood flow mediated by central nervous system. American Journal of Physiology 251 E644-E647.

Jansson L, Andersson A, Bodin B \& Kallskog O 2007 Pancreatic islet blood flow during euglycaemic, hyperinsulinaemic clamp in anaesthetized rats. Acta Physiologica 189 319-324. (doi:10.1111/j. 1748-1716.2006.01666.x)

Jung SK, Kauri LM, Qian WJ \& Kennedy RT 2000 Correlated oscillations in glucose consumption, oxygen consumption, and intracellular free $\mathrm{Ca}(2+)$ in single islets of Langerhans. Journal of Biological Chemistry 275 6642-6650. (doi:10.1074/jbc.275. 9.6642)

Kemeny AA, Jakubowski J, Stawowy A, Smith C \& Timperley WR 1987 Changes of blood flow in oestrogen-induced hyperplastic anterior pituitary lobe following bromocriptine administration. British Journal of Neurosurgery 1 243-250. (doi:10.3109/0268869870 9035308)

Kemp PJ, Telezhkin V, Wilkinson WJ, Mears R, Hanmer SB, Gadeberg HC, Muller CT, Riccardi D \& Brazier SP 2009 Enzyme-linked oxygen sensing by potassium channels. Annals of the New York Academy of Sciences 1177 112-118. (doi:10.1111/j.1749-6632.2009.05025.x)
King GL \& Johnson SM 1985 Receptor-mediated transport of insulin across endothelial cells. Science 227 1583-1586. (doi:10.1126/ science.3883490)

Kjems LL, Ravier MA, Jonas JC \& Henquin JC 2002 Do oscillations of insulin secretion occur in the absence of cytoplasmic $\mathrm{Ca}^{2+}$ oscillations in beta-cells? Diabetes 51 (Suppl 1) S177-S182. (doi:10. 2337/diabetes.51.2007.S177)

Knobil E, Neill JD, Greenwald GS, Markert C \& Donald W 1994. The Physiology of Reproduction, New York: Raven Press.

Kragl M \& Lammert E 2010 Basement membrane in pancreatic islet function. Advances in Experimental Medicine and Biology 654 217-234. (doi:10.1007/978-90-481-3271-3_10)

Kruse A, Broholm H, Rubin I, Schmidt K \& Lauritzen M 2002 Nitric oxide synthase activity in human pituitary adenomas. Acta Neurologica Scandinavica 106 361-366. (doi:10.1034/j.1600-0404.2002.01138.x)

Lafont C, Desarmenien MG, Cassou M, Molino F, Lecoq J, Hodson D, Lacampagne A, Mennessier G, El Yandouzi T, Carmignac D et al. 2010 Cellular in vivo imaging reveals coordinated regulation of pituitary microcirculation and GH cell network function. PNAS 107 4465-4470. (doi:10.1073/pnas.0902599107)

Lai EY, Persson AE, Bodin B, Kallskog O, Andersson A, Pettersson U, Hansell P \& Jansson L 2007 Endothelin-1 and pancreatic islet vasculature: studies in vivo and on isolated, vascularly perfused pancreatic islets. American Journal of Physiology. Endocrinology and Metabolism 292 E1616-E1623. (doi:10.1152/ajpendo.00640.2006)

Lammert E, Gu G, McLaughlin M, Brown D, Brekken R, Murtaugh LC, Gerber HP, Ferrara N \& Melton DA 2003 Role of VEGF-A in vascularization of pancreatic islets. Current Biology 13 1070-1074. (doi:10.1016/S0960-9822(03)00378-6)

Magoulas C, McGuinness L, Balthasar N, Carmignac DF, Sesay AK, Mathers KE, Christian H, Candeil L, Bonnefont X, Mollard P et al. 2000 A secreted fluorescent reporter targeted to pituitary growth hormone cells in transgenic mice. Endocrinology 141 4681-4689. (doi:10.1210/en.141.12.4681)

Matthews DR, Naylor BA, Jones RG, Ward GM \& Turner RC 1983 Pulsatile insulin has greater hypoglycemic effect than continuous delivery. Diabetes 32 617-621. (doi:10.2337/diabetes.32.7.617)

McCuskey RS \& Chapman TM 1969 Microscopy of the living pancreas in situ. American Journal of Anatomy 126 395-407. (doi:10.1002/aja. 1001260402)

Moldovan S \& Brunicardi FC 2001 Endocrine pancreas: summary of observations generated by surgical fellows. World Journal of Surgery 25 468-473. (doi:10.1007/s002680020339)

Mollard P \& Schlegel W 1996 Why are endocrine pituitary cells excitable? Trends in Endocrinology and Metabolism 7 361-365. (doi:10. 1016/S1043-2760(96)00186-5)

Mollard P, Seward EP \& Nowycky MC 1995 Activation of nicotinic receptors triggers exocytosis from bovine chromaffin cells in the absence of membrane depolarization. PNAS 92 3065-3069. (doi:10. 1073 /pnas.92.7.3065)

Montagnani M, Chen H, Barr VA \& Quon MJ 2001 Insulin-stimulated activation of eNOS is independent of $\mathrm{Ca}^{2+}$ but requires phosphorylation by Akt at Ser(1179). Journal of Biological Chemistry 276 30392-30398. (doi:10.1074/jbc.M103702200)

Nakamura M, Kitamura H, Konishi S, Nishimura M, Ono J, Ina K, Shimada T \& Takaki R 1995 The endocrine pancreas of spontaneously diabetic $\mathrm{db} / \mathrm{db}$ mice: microangiopathy as revealed by transmission electron microscopy. Diabetes Research and Clinical Practice 30 89-100. (doi:10.1016/0168-8227(95)01155-2)

Nyman LR, Wells KS, Head WS, McCaughey M, Ford E, Brissova M, Piston DW \& Powers AC 2008 Real-time, multidimensional in vivo imaging used to investigate blood flow in mouse pancreatic islets. Journal of Clinical Investigation 118 3790-3797. (doi:10.1172/JCI36209)

Nyman LR, Ford E, Powers AC \& Piston DW 2010 Glucose-dependent blood flow dynamics in murine pancreatic islets in vivo. American Journal of Physiology. Endocrinology and Metabolism 298 E807-E814. (doi:10.1152/ajpendo.00715.2009) 
Olsson R, Jansson L, Andersson A \& Carlsson PO 2000 Local blood flow regulation in transplanted rat pancreatic islets: influence of adenosine, angiotensin II, and nitric oxide inhibition. Transplantation 70 280-287. (doi:10.1097/00007890-200007270-00007)

Peppiatt CM, Howarth C, Mobbs P \& Attwell D 2006 Bidirectional control of CNS capillary diameter by pericytes. Nature 443 700-704. (doi:10.1038/nature05193)

Prabhakar NR $2006 \mathrm{O}_{2}$ sensing at the mammalian carotid body: why multiple $\mathrm{O}_{2}$ sensors and multiple transmitters? Experimental Physiology 91 17-23. (doi:10.1113/expphysiol.2005.031922)

Ravier MA, Gilon P \& Henquin JC 1999 Oscillations of insulin secretion can be triggered by imposed oscillations of cytoplasmic $\mathrm{Ca}^{2+}$ or metabolism in normal mouse islets. Diabetes 48 2374-2382. (doi:10.2337/diabetes.48.12.2374)

Ravier MA, Guldenagel M, Charollais A, Gjinovci A, Caille D, Sohl G, Wollheim CB, Willecke K, Henquin JC \& Meda P 2005 Loss of connexin 36 channels alters beta-cell coupling, islet synchronization of glucose-induced $\mathrm{Ca}^{2+}$ and insulin oscillations, and basal insulin release. Diabetes 54 1798-1807. (doi:10.2337/diabetes.54.6.1798)

Richards OC, Raines SM \& Attie AD 2010 The role of blood vessels, endothelial cells, and vascular pericytes in insulin secretion and peripheral insulin action. Endocrine Reviews 31 343-363. (doi:10. 1210/er.2009-0035)

Rinehart JF \& Farquhar MG 1955 The fine vascular organization of the anterior pituitary gland; an electron microscopic study with histochemical correlations. Anatomical Record 121 207-239. (doi:10.1002/ar.1091210206)

Robinson ICAF \& Hindmarsh PC 1999 The importance of the secretory pattern of growth hormone for statural growth. In Handbook of Physiology, Section 7. The Endocrine System, vol 5, pp 329-395. Ed. JL Kostyo. New York: Oxford University Press.

Rucker HK, Wynder HJ \& Thomas WE 2000 Cellular mechanisms of CNS pericytes. Brain Research Bulletin 51 363-369. (doi:10.1016/ S0361-9230 (99) 00260-9)

Salehi A, Carlberg M, Henningson R \& Lundquist I 1996 Islet constitutive nitric oxide synthase: biochemical determination and regulatory function. American Journal of Physiology 270 C1634-C1641.

Sanchez-Cardenas C, Fontanaud P, He Z, Lafont C, Meunier AC, Schaeffer M, Carmignac D, Molino F, Coutry N, Bonnefont X et al. 2010 Pituitary growth hormone network responses are sexually dimorphic and regulated by gonadal steroids in adulthood. PNAS 107 21878-21883. (doi:10.1073/pnas.1010849107)

Santos RM, Rosario LM, Nadal A, Garcia-Sancho J, Soria B \& Valdeolmillos M 1991 Widespread synchronous $\left[\mathrm{Ca}^{2+}\right]_{\mathrm{i}}$ oscillations due to bursting electrical activity in single pancreatic islets. Pflügers Archiv 418 417-422. (doi:10.1007/BF00550880)

Sartor O, Bowers CY \& Chang D 1985 Parallel studies of His-DTrpAla-Trp-DPhe-Lys- $\mathrm{NH}_{2}$ and human pancreatic growth hormonereleasing factor-44- $\mathrm{NH}_{2}$ in rat primary pituitary cell monolayer culture. Endocrinology 116 952-957. (doi:10.1210/endo-116-3-952)

Satoh H, Inokuchi T, Shimizu M, Obayashi H \& Nakashima Y 1989 Ultrastructure of the hypophyseal portal vessel in mature rats - SEM and TEM observations. Kurume Medical Journal 36 91-94.

Schaeffer M, Hodson DJ, Lafont C \& Mollard P 2010 Functional importance of blood flow dynamics and partial oxygen pressure in the anterior pituitary. European Journal of Neuroscience 32 2087-2095. (doi:10.1111/j.1460-9568.2010.07525.x)
Schlegel W, Winiger BP, Mollard P, Vacher P, Wuarin F, Zahnd GR, Wollheim CB \& Dufy B 1987 Oscillations of cytosolic $\mathrm{Ca}^{2+}$ in pituitary cells due to action potentials. Nature 329 719-721. (doi:10. 1038/329719a0)

Sonntag WE, Lynch C, Thornton P, Khan A, Bennett S \& Ingram R 2000 The effects of growth hormone and IGF-1 deficiency on cerebrovascular and brain ageing. Journal of Anatomy 197 575-585. (doi:10.1017/S002187829900713X)

Sparrow RA \& Beckingham IJ 1989 Islet blood flow following insulin administration. Journal of Anatomy 163 75-81.

Stan RV, Kubitza M \& Palade GE 1999 PV-1 is a component of the fenestral and stomatal diaphragms in fenestrated endothelia. PNAS 96 13203-13207. (doi:10.1073/pnas.96.23.13203)

Steil GM, Ader M, Moore DM, Rebrin K \& Bergman RN 1996 Transendothelial insulin transport is not saturable in vivo. No evidence for a receptor-mediated process. Journal of Clinical Investigation 97 1497-1503. (doi:10.1172/JCI118572)

Stojilkovic SS, Zemkova H \& Van Goor F 2005 Biophysical basis of pituitary cell type-specific $\mathrm{Ca}^{2+}$ signaling-secretion coupling. Trends in Endocrinology and Metabolism 16 152-159. (doi:10.1016/j.tem. 2005.03.003)

Svensson AM, Abdel-Halim SM, Efendic S, Jansson L \& Ostenson CG 1994 Pancreatic and islet blood flow in F1-hybrids of the noninsulin-dependent diabetic GK-Wistar rat. European Journal of Endocrinology 130 612-616. (doi:10.1530/eje.0.1300612)

Svensson AM, Ostenson CG \& Jansson L 2000 Age-induced changes in pancreatic islet blood flow: evidence for an impaired regulation in diabetic GK rats. American Journal of Physiology. Endocrinology and Metabolism 279 E1139-E1144.

Tannenbaum GS, Martin JB \& Colle E 1976 Ultradian growth hormone rhythm in the rat: effects of feeding, hyperglycemia, and insulin-induced hypoglycemia. Endocrinology 99 720-727. (doi:10. 1210/endo-99-3-720)

Tse A, Tse FW, Almers W \& Hille B 1993 Rhythmic exocytosis stimulated by GnRH-induced calcium oscillations in rat gonadotropes. Science 260 82-84. (doi:10.1126/science.8385366)

Tsumori M, Murakami Y, Koshimura K \& Kato Y 2002 Growth hormonereleasing hormone and gonadotropin-releasing hormone stimulate nitric oxide production in 17beta-estradiol-primed rat anterior pituitary cells. Endocrine 17 215-218. (doi:10.1385/ENDO:17:3:215)

Turner HE, Harris AL, Melmed S \& Wass JA 2003 Angiogenesis in endocrine tumors. Endocrine Reviews 24 600-632. (doi:10.1210/er. 2002-0008)

Waite E, Lafont C, Carmignac D, Chauvet N, Coutry N, Christian H, Robinson I, Mollard P \& Le Tissier P 2010 Different degrees of somatotroph ablation compromise pituitary growth hormone cell network structure and other pituitary endocrine cell types. Endocrinology 151 234-243. (doi:10.1210/en.2009-0539)

Wildt L, Hausler A, Marshall G, Hutchison JS, Plant TM, Belchetz PE \& Knobil E 1981 Frequency and amplitude of gonadotropin-releasing hormone stimulation and gonadotropin-secretion in the rhesusmonkey. Endocrinology 109 376-385. (doi:10.1210/endo-109-2-376)

Received in final form 27 April 2011

Accepted 23 May 2011

Made available online as an Accepted Preprint 26 May 2011 